\title{
Human Resource Information System and Work Stress during COVID-19 Pandemic
}

\author{
Misnal Munir ${ }^{1}$, Amaliyah $^{2}$, Moses Glorino Rumambo Pandin ${ }^{3 *}$ \\ ${ }^{1}$ Faculty of Philosophy, Universitas Gadjah Mada, Yogyakarta, Indonesia \\ ${ }^{2}$ Universitas Trilogi, Jakarta, Indonesia \\ ${ }^{3}$ Faculty of Humanities, Universitas Airlangga, Surabaya, Indonesia
}

Corresponding Author:

moses.glorino@fib.unair.ac.id

Faculty of Humanities, Universitas Airlangga

Jl. Dharmawangsa dalam Selatan, Campus B

Surabaya- East Java, Indonesia, 60286

\begin{abstract}
The increasingly rapid flow of technological development is now a tool to improve backwardness, renew the system, as well as a means of improvement in various aspects of life. For companies, the development of information and communication technology is a new innovation or breakthrough to improve service quality. Various benefits provided by technology and information. However, if not handled properly, technology and information will become a boomerang for an organization. HRIS is the application of HRM functions in the application of information and communication technology. The concept of HRIS as a digital form of HRM is increasing along with the outbreak of the Covid-19 pandemic which has caused a large loss impact on all lines of life. The limitation of social interaction in an effort to prevent the wider spread of covid-19 and the higher number of casualties causes business activities to stall. This research uses quantitative methods with a study sample of 100 randomly selected. This study aims to see how clarity of high-tech goals in human resources management, perceived benefits, perceived ease of use, company conditions that can influence attitudes towards HRIS.
\end{abstract}

Keywords: Hi-Tech HR, Human resources management, Work Stress, Covid-19

\section{INTRODUCTION}

Human resources are one of the main assets in an organization, which can provide invaluable contributions in the strategy of achieving organizational goals. One example of the importance of the contribution of human resources in a company can be seen from the production process. Where when the company already has financial strength, raw materials are met, and the latest technology but the absence of good human resources, the production process will not run smoothly (Syamsuddinor, 2014). In order for management activities to run well, companies must have knowledgeable and employees skilled highly and efforts to 
manage the company as optimal as possible so that employee performance increases (Rahayuningsih et al., 2019).

The existence of human resource management is very important for companies in managing, and using available human resources in order to function effectively and efficiently. While the quality of Indonesian human resources is currently at the lowest position when compared to workers in other countries (www.suara.com). Then research conducted by the World Bank found that Indonesia was in 87th position out of 157 countries so that Indonesia was in dire need of overall improvement and improvement in every aspect, especially in human resource management.

Over time, the development of technology and information in the world has had a different impact and influence on almost all aspects of life. Various needs in all fields of life such as the economy, social culture, health, agriculture, industry and other fields can be supported and fulfilled easily and quickly through information and communication technology (Yusliza et al., 2014). Mahedi and Fartash (2012) explain that the development of information and communication technology can change the way organizations or companies run their businesses, contribute to changes in structure and function as well as improve performance and effectiveness, while for Parry (2011), technological development information and communication are new ways to bring organizations to success until the emerges Human Resource Information System (HRIS).

The concept of HRIS is inseparable from a general understanding of human resource management (HRM). It can be said that HRIS is the application of HRM functions in the application of information and communication technology. The study of the concept of HRIS as a digital form of HRM is increasing along with the outbreak of the Covid-19 pandemic which has caused a large loss impact on all lines of life. The limitation of social interaction in an effort to prevent the wider spread of covid-19 and the higher number of casualties it causes business activities to stall. Companies cannot carry out their production activities as usual because of the prohibition from the government to operate and because of the decreasing market demand for the products and services produced. Therefore, every company strives to formulate the most appropriate strategy to be implemented in order to maintain its survival, including in terms of managing its human resources. This is also one of the main bases of a paradigm shift in human resource management from traditional concepts carried out using a direct approach, namely by face-to-face interaction between human resource managers and employees, to rely more on digital media that is in accordance with health protocols, which was enforced during the covid-19 pandemic (Shil et al., 2020).

Companies are faced with difficult choices, namely to carry out massive efficiency or try to maintain their human resources at the risk of increasing operating expenses that must be borne without being balanced with income that is in accordance with needs. On the other hand, every employee whose employment relationship has not been terminated by the company feels enormous work pressure because they have to work with a new work model, namely working from home (remote working - for the type of work that allows working in this way), as well as working. With worry because at any time you can receive notification of termination of employment by the company. Based on this, the employee work pressure which continues to increase has become a prominent issue (Kaushik \& Guleria, 2020). Again, HRM practices are challenged. Especially in the context of implementing HRIS, it is not only related to the attitude of employees who tend to accept or reject the digital version of HRM 
practices which must be the main concern, but whether the application of HRIS can also overcome the issue of the increasing work pressure felt by employees.

Conceptually, higher work pressure has an impact on decreasing job satisfaction (Yu et.al. 2020). Employee satisfaction at work is a construct that can be measured using various approaches, one of which is by looking at the attitudes of employees (Ariani \& Dalle, 2019). That is, to be able to find out how high the work pressure felt by employees can refer to the results of the analysis of employee attitudes. A positive attitude represents a low work pressure on employees. Conversely, a negative attitude shows that employees experience high work pressure.

The researcher will look at how clear the objectives of HRIS are, the perceived benefits, perceived ease of use, company conditions that can influence attitudes towards HRIS. The discussion will be related to the current industrial situation which is experiencing many operational limitations due to the impact of the Covid-19 pandemic. The results obtained from this discussion are expected to provide a bright spot regarding the importance of implementing HRIS, not only to increase the effectiveness and efficiency of HRM activities, but also to address the main issues that have arisen, namely regarding the increasing work pressure felt by employees, which in the long risk causing lower company performance.

\section{METHOD}

This study used a quantitative approach. Seeing the size of the study population, researchers chose 100 numbers of research samples to be chosen at random. The research object of PT XYZ, which is one of the major companies in Indonesia

\section{RESULTS AND DISCUSSION}

Table 1 Results of Testing Convergent Validity

\begin{tabular}{|l|c|c|c|}
\hline \multicolumn{1}{|c}{ Variable } & Indicator & Outer Loading & Description \\
\hline \multirow{3}{*}{ Clarity of Purpose HRIS } & $\mathrm{x} 11$ & 0.860 & Valid Convergent \\
\cline { 2 - 4 } & $\mathrm{x} 12$ & 0.803 & Valid Convergent \\
\cline { 2 - 4 } & $\mathrm{x} 13$ & 0.867 & Valid Convergent \\
\hline \multirow{4}{*}{ Benefits of HRIS } & $\mathrm{X} 21$ & 0.837 & Valid Convergent \\
\cline { 2 - 4 } & $\mathrm{x} 22$ & 0.843 & Valid Convergent \\
\cline { 2 - 4 } & $\mathrm{x} 23$ & 0.819 & Valid Convergent \\
\hline \multirow{4}{*}{ Ease of Use } & $\mathrm{x} 24$ & 0.750 & Valid Convergent \\
\cline { 2 - 4 } & $\mathrm{x} 31$ & 0.787 & Valid Convergent \\
\cline { 2 - 4 } & $\mathrm{x} 32$ & 0.814 & Valid Convergent \\
\cline { 2 - 4 } & $\mathrm{x} 33$ & 0.765 & Valid Convergent \\
\cline { 2 - 4 } & $\mathrm{x} 34$ & 0.819 & Valid Convergent \\
\cline { 2 - 4 } & $\mathrm{x} 35$ & 0.782 & Valid Convergent \\
\cline { 2 - 4 } & $\mathrm{x} 36$ & 0.773 & Valid Convergent \\
\hline Conditions Company & $\mathrm{x} 37$ & 0.802 & Valid Convergent \\
\hline
\end{tabular}




\begin{tabular}{||c|c|c|c|}
\hline \multirow{4}{*}{} & $\mathrm{x} 42$ & 0.743 & Valid Convergent \\
\cline { 2 - 4 } & $\mathrm{x} 43$ & 0.573 & Valid Convergent \\
\cline { 2 - 4 } & $\mathrm{x} 44$ & 0.749 & Valid Convergent \\
\cline { 2 - 4 } & $\mathrm{x} 45$ & 0.898 & Valid Convergent \\
\cline { 2 - 4 } & $\mathrm{x} 46$ & 0.863 & Valid Convergent \\
\cline { 2 - 4 } & $\mathrm{x} 47$ & 0.762 & Valid Convergent \\
\hline \multirow{2}{*}{$\begin{array}{c}\text { Attitudes Employees' } \\
\text { Implementation of HRIS }\end{array}$} & $\mathrm{x} 48$ & 0.685 & Valid Convergent \\
\cline { 2 - 4 } & $\mathrm{y} 11$ & 0.858 & Valid Convergent \\
\hline
\end{tabular}

Source: primary data is processed, 2020

Based on the table above shows that all outer loading in the measurement of each of the variables have outer loading above 0.5 has been fulfilled thus all indicators as a measure of the construct of the four research variables are convergent valid.

Table 2 Testing Results Discriminant Validity

\begin{tabular}{|c|c|c|c|c|c|c|c|c|}
\hline \multirow{2}{*}{ Variables } & \multirow{2}{*}{$\begin{array}{c}\text { AVE } \\
\text { AVE }\end{array}$} & \multirow{2}{*}{ Root } & \multicolumn{4}{|c|}{ Correlation Scores Between Latent Variables } & \multirow{2}{*}{ Information } \\
\cline { 5 - 8 } & & $\mathrm{X} 1$ & $\mathrm{X} 2$ & $\mathrm{X} 3$ & $\mathrm{X} 4$ & $\mathrm{Y} 1$ & \\
\hline $\mathrm{X} 1$ & 0.712 & 0.844 & & 0.786 & 0.727 & 0.667 & 0.656 & $\begin{array}{c}\text { Valid } \\
\text { Discriminant }\end{array}$ \\
\hline $\mathrm{X} 2$ & 0.661 & 0.813 & 0.786 & & 0.718 & 0.645 & 0.647 & $\begin{array}{c}\text { Valid } \\
\text { Discriminant }\end{array}$ \\
\hline $\mathrm{X} 3$ & 0.627 & 0.792 & 0.727 & 0.718 & & 0.744 & 0.711 & $\begin{array}{c}\text { Valid } \\
\text { Discriminant }\end{array}$ \\
\hline Y1 & 0.576 & 0.759 & 0.667 & 0.645 & 0.744 & & 0.752 & $\begin{array}{c}\text { Valid } \\
\text { Discriminant }\end{array}$ \\
\hline
\end{tabular}

Source: Primary data processed, 2020

Based on the table above it can be seen that all four variables, the root value of AVE is greater than the correlation value between latent variables, thus fulfilling the discriminant validity test.

Table 3. Testing Results Reliability Composite

\begin{tabular}{|l|l|l|}
\hline Variable & Composite Reliability & Description \\
\hline $\mathrm{X} 1$ & 0.881 & Reliable \\
\hline $\mathrm{X} 2$ & 0.886 & Reliable \\
\hline $\mathrm{X} 3$ & 0.922 & Reliable \\
\hline $\mathrm{X} 4$ & 0.915 & Reliable \\
\hline Y1 & 0.877 & Reliable \\
\hline
\end{tabular}

Sources: Primary data is processed, 2020 
Based on the table above, the test results showed all values of composite reliability show values greater than 0.7 , the composite reliability is met. So it can be concluded that all indicators are indeed a measure of their respective constructs.

\section{PLS Analysis Results \\ Goodness of Fit Model}

Rated $\mathrm{R}^{2}$ of each of the endogenous variables as follows:

Measurement of endogenous variables Employee Attitude Toward Implementation of HRIS obtained $\mathrm{R}^{2}$ of 0621 , or $62.1 \%$. This indicates $62.1 \%$ of Employee Attitudes toward HRIS Implementation is influenced by the Clarity of HRIS Objectives, HRIS Benefits, Ease of Use, and Company Conditions.

Thus the predictive relevance value $\left(\mathrm{Q}^{2}\right)$ is obtained as follows:

$$
\begin{aligned}
& \mathrm{Q}^{2}=1-\left(1-\mathrm{R}_{1}^{2}\right) \\
& \mathrm{Q}^{2}=1-(1-0.621) \\
& \mathrm{Q}^{2}=0.621
\end{aligned}
$$

The calculation results show a predictive-relevance value of 0.621 or $62.1 \%$ is high enough so that the model is worthy of being said to have relevant predictive value. Value Relevance predictive of $62.1 \%$ indicates that the diversity of data that can be explained by the PLS model built amounted to $62.1 \%$ or in other words, the information contained in the data $62.1 \%$ can be explained by the model. While the remaining $37.9 \%$ is explained by other variables (not yet contained in the model) and error.

Table 4. Results of Model Outer the Clarity of Purpose HRIS

\begin{tabular}{lclll}
\hline Indicator & $\begin{array}{c}\text { Outer } \\
\text { Loading }\end{array}$ & T-statistic & P-value & Description \\
\hline $\mathrm{x} 11$ & 0.860 & 69308 & 0000 & significant \\
\hline $\mathrm{x} 12$ & 0.803 & 15497 & 0000 & significant \\
\hline $\mathrm{x} 13$ & 0.867 & 66187 & 0.000 & significant \\
\hline
\end{tabular}

Source: Primary data is processed, 2020

Based on the test results outer the model above shows that the Clarity of HRIS Objectives is reflected by three indicators. From the three indicators, it appears that the third indicator has the outer loading highest. This indicates that the measurement of the Clarity of HRIS Objectives is dominated by $\mathrm{x} 13$.

Table 5. Results Outer Model on HRIS Benefit Variable

\begin{tabular}{lllll}
\hline Indicator & Outer Loading & T-statistic & P-value & Information \\
\hline $\mathrm{x} 21$ & 0.837 & 14,913 & 0,000 & significant \\
\hline $\mathrm{x} 22$ & 0.843 & 32,582 & 0,000 & significant \\
\hline $\mathrm{x} 23$ & 0.819 & 17,450 & 0,000 & significant \\
\hline $\mathrm{x} 24$ & 0.750 & 11,603 & 0,000 & significant \\
\hline
\end{tabular}

Source: Primary data processed, 2020 
Based on the results testing the outer model above shows that the benefits of HRIS are reflected by four indicators. From the four indicators, it appears that the second indicator has the highest outer loading value. This indicates that the measurement of HRIS Benefits is dominated by $x 22$.

Table 6. Results of Outer Model on Variable Ease of Use

\begin{tabular}{lllll}
\hline Indicators & Loading Outer & T-statistic & P-value & Description \\
\hline $\mathrm{x} 31$ & 0787 & 13438 & 0000 & significant \\
\hline $\mathrm{x} 32$ & 0814 & 13771 & 0000 & significant \\
\hline $\mathrm{x} 33$ & 0765 & 43819 & 0000 & significant \\
\hline $\mathrm{x} 34$ & 0819 & 33546 & 0000 & significant \\
\hline $\mathrm{x} 35$ & 0782 & 19413 & 0000 & significant \\
\hline $\mathrm{x} 36$ & 0773 & 24296 & 0.000 & significant \\
\hline $\mathrm{x} 37$ & 0.802 & 12,315 & 0,000 & significant \\
\hline
\end{tabular}

Source: Primary data processed, 2020

Based on the results of the test outer model above it can be seen that the Ease of Use is reflected by seven indicators. From the seven indicators it appears that the fourth indicator has the highest outer loading value. This indicates that the Ease of Use measurement is dominated by x34.

Table 7. Results Outer Model on Company Conditions Variable

\begin{tabular}{lllll}
\hline Indicator & Outer Loading & T-statistic & P-value & Information \\
\hline $\mathrm{x} 41$ & 0.755 & 14.468 & 0.000 & significant \\
\hline $\mathrm{x} 42$ & 0.743 & 12144 & 0.000 & significant \\
\hline $\mathrm{x} 43$ & 0.573 & 8.191 & 0.000 & significant \\
\hline $\mathrm{x} 44$ & 0.749 & 11.178 & 0.000 & significant \\
\hline $\mathrm{x} 45$ & 0.898 & 201.962 & 0.000 & significant \\
\hline $\mathrm{x} 46$ & 0.863 & 35.396 & 0.000 & significant \\
\hline $\mathrm{x} 47$ & 0.762 & 27.831 & 0000 & significant \\
\hline $\mathrm{x} 48$ & 0685 & 17618 & 0.000 & significant \\
\hline
\end{tabular}

Source: primary data is processed, 2020

Based on the test results, the outer model above shows the Company's condition reflected by the eight indicators. From the eight indicators it appears that the fifth indicator has the highest outer loading value. This indicates that the measurement of the Company's condition is dominated by $\mathrm{x} 45$.

Table 8. Results Outer Model on Variable Attitude Employees' Implementation of HRIS

\begin{tabular}{lllll}
\hline Indicators & Outer Loading & T-statistic & P-value & Description \\
\hline y11 & 0.858 & 77142 & 0000 & significantly \\
\hline
\end{tabular}




\begin{tabular}{rrrrr} 
Y12 & 0.909 & 92388 & 0000 & significantly \\
\hline
\end{tabular}

Source: Primary data is processed, 2020

Based on the test results outer models above that Employee Attitudes toward HRIS Implementation is reflected by two indicators. The second indicator shows that the second indicator has the highest outer loading value. This indicates that the measurement of Employee Attitudes Toward HRIS Implementation is dominated by y12.

Table 9. Test Result of Direct Effect in Inner Model

\begin{tabular}{lllll}
\hline Direct Effect of & Inner Weight & T-statistic & P-value & Conclusion \\
\hline $\mathrm{X} 1$-> Y1 & 0.148 & 2,080 & 0.037 & significant \\
\hline $\mathrm{X} 2$-> Y1 & 0.161 & 3.293 & 0.001 & significant \\
\hline $\mathrm{X} 3$-> Y1 & 0.085 & 3.038 & 0.002 & significant \\
\hline $\mathrm{X} 4$-> Y1 & 0.477 & 21.637 & 0.000 & significant \\
\hline
\end{tabular}

Source: Primary data processed, 2020

Based on the results of the above test, it can be concluded several things as follows:

a) Testing the direct effect of Clarity of HRIS Objectives on Employee Attitudes Toward HRIS Implementation coefficient obtained value inner weight of 0.148 , meaning that the higher the Clarity of HRIS Objectives will lead to the higher the Attitude of Employees Against HRIS Implementation.

b) Testing the direct effect of the Benefits of HRIS on Employee Attitudes Toward HRIS Implementation coefficient values obtained inner weight by 0.161 , meaning that the higher benefits of HRIS will result in the higher attitude of employees towards the implementation of HRIS.

c) Testing the direct effect between Ease of Use on Employee Attitudes Toward HRIS Implementation coefficient value obtained inner weight of 0.085 is, meaning that the higher the Ease of Use will result in the higher attitude of Employees towards the Implementation of HRIS.

d) Testing the direct effect of the Company's Conditions on Employee Attitudes Toward HRIS Implementation coefficient value obtained inner by 0.477 , meaning that the higher the condition of the company will result in the higher attitude of employees towards the application of HRIS.

\section{DISCUSSION}

The results of the above processing show that all the independent variables in this study are clarity of HRIS objectives, the benefits of using HRIS, ease of use of HRIS and HRIS company conditions have a significant effect on the dependent variable namely employee attitudes regarding digital HRM.

\section{Clarity of Purpose}

Testing the direct effect between Clarity of HRIS Objectives on Employee Attitudes toward HRIS Implementation coefficient obtained value inner weight of 0.148 , meaning that 
the higher the Clarity of HRIS Objectives will lead to the higher the Attitude of Employees against HRIS Implementation.

HRIS helps organizations in managing their human resources and provides added value to the role of HR in organizations that certainly affects the competitive advantage of the organization or company, HRIS also helps organizations to improve service quality, and in addition to that HRIS also provides efficiency time and cost in various activities in the organization.

Basically, employees like a clear task, knowing exactly what will be achieved and how to achieve it. Clarity of purpose has the definition that all policies made by the company should have clear objectives regarding what will be achieved. Clarity of purpose of the HRM program must be clear so that the employees no longer need to ask questions about the purpose of the implementation of a program, and implementation of the HRIS program can be done well and directed.

In accordance with current conditions, the aim of HRIS is not only to increase the effectiveness and efficiency of human resource management activities at PT XYZ, but also to ensure that the company and employees remain digitally connected. This is very important because with the new work model, namely remote working, companies and their employees cannot physically interact directly. Efforts to overcome this limitation are one of the main objectives of implementing HRIS in PT XYZ.

According to Mauro \& Borges-Andrade (2019), HRIS is a form of innovation in management methods in managing employees. Broadly speaking, there are eight objectives to be achieved from the implementation of HRIS, namely: 1) Enabling the implementation of a quality HR process; 2) The company can carry out employee development in a variety of special situations, which in the context of this study is in a restricted work situation due to the outbreak of the Covid-19 pandemic; 3) Increase the company's ability to process information; 4) Increase the capacity of the company in controlling all its resources; 5) Broaden the knowledge of employees; 6) Facilitate access to information, both by companies and employees; 7) Enable employees to carry out their work, especially in the current covid19 situation; and 8) Facilitate documentation and formalization of information.

Referring to the employee's point of view, clarity of purpose is desirable because the employee's condition is under enormous work pressure. The implementation of HRIS with the aim of facilitating connectivity between the company and employees is considered a form of company concern for the conditions experienced and felt by employees, and can also be interpreted as a company's good intention to retain its employees. Therefore, the more employees understand HRIS objectives clearly, the employees will have a more positive attitude towards HRIS implementation at PT XYZ.

\section{Benefits of HRIS}

Testing the direct effect of the Benefits of HRIS on Employee Attitudes toward HRIS Implementation coefficient values obtained inner weight by 0.161 , meaning that the higher the benefits of HRIS will result in the higher attitude of employees towards the implementation of HRIS.

The system is a collection of components that work together to achieve certain goals. The system functions to receive input, process input, and produce output. Inputs and outputs come from outside the system, or come from the environment the system is located. 
Therefore, the system will interact with its environment. Systems that are able to interact with their environment will be able to last a long time, and vice versa.

The benefits of HRIS should be a level where someone believes that the use of a particular system will be able to improve the work performance of that person. Acceptance of technology by users is determined by two types of motivation, namely intrinsic motivation and extrinsic motivation. Intrinsic motivation arises because of the expectations felt by the individual itself from the results of interacting with an information technology system application. While extrinsic motivation arises because of the expectations for the use of certain information technology system applications received from outside the award for improved performance. Likewise with HRIS, if this program provides motivation extrinsic to employees such as improving employee performance, it will indirectly lead to positive employee attitudes towards the application of HRIS or the new technology.

In the context of this research, the implementation of HRIS by PT XYZ has various benefits that are felt directly or indirectly by both the company and employees. The direct benefits felt by the company and employees are in the form of maintaining a working relationship, so that even though we have to use a new work model, namely remote working, there are still important processes that can be carried out. The second benefit is in the form of maintaining the survival of the company because the management of human resources who have an important role can still be carried out using HRIS. The next benefit is in the form of a reduction in the work pressure felt by employees because through HRIS, employees can still be connected to the company, as well as allowing employees to convey the various complaints they feel while carrying out remote working in a covid-19 pandemic situation.

Based on the important benefits of implementing HRIS, employees' attitudes towards HRIS implementation also become more positive along with the greater benefits felt by employees, especially in reducing the work pressure felt by employees. This is in accordance with the findings of Pich \& Sardjono (2020) which states that information systems, which in the context of this research are HRIS, have an important role as a medium that allows communication to be maintained within the scope of the company during the Covid-19 pandemic. Although the information system basically has had great benefits in increasing work effectiveness and efficiency, especially during the Covid-19 period, these benefits are felt to be even greater. In fact, it can also be said that companies that do not immediately adapt by maximizing the role of information systems during the Covid-19 period will experience business failures that can lead to bankruptcy.

\section{Ease of Use}

Testing the direct effect between Ease of Use on Employee Attitudes Toward HRIS Implementation coefficient value obtained inner weight of 0.085 is, meaning that the higher the Ease of Use will result in the higher attitude of Employees towards the Implementation of HRIS.

Ease of Use is defined as the trust of individuals where if they use a particular system it will be free of effort (Mathieson, 1991). So if someone believes that a technology is easy to use then that person will use it. So this convenience variable gives an indication that a system is made not to complicate the user, but rather a system created with the aim of providing convenience for the wearer. Thus, someone who uses a particular system will work easier when compared to someone who works manually. Several previous studies have 
proven that the perception of Ease of Use has an influence on the attitude of the use of technology, including research conducted by Ramadhani (2008).

Based on this definition it can be seen that the ease of use is also a belief about the decision making process. If someone feels confident that the information system is easy to use then he will use it. Conversely, if someone feels sure that the information system is not easy to use then he will not use it. As with other technologies, HRIS is also made to simplify and improve the quality of employees in a company, when a system can simplify one's work then that person will have a tendency greater towards the program, giving rise to a good attitude towards implementing HRIS Company.

Moreover, if it is related to the covid-19 pandemic situation which causes high work pressure felt by employees, the implementation of HRIS at PT XYZ is something that is very much needed by the company and employees. If employees feel that the HRIS applied to PT $\mathrm{XYZ}$ is an information system that is easy to use, then employees will have the perception that its implementation will not increase work pressure for employees. With the existence of HRIS which becomes the liaison between the company and employees, as well as the ease of use of the system, the work pressure of employees will decrease, which in turn encourages more positive employee attitudes towards HRIS implementation at PT XYZ.

\section{Company Conditions}

Testing the direct effect of Company Conditions on Employee Attitudes toward HRIS Implementation coefficient value obtained inner by 0.477 , meaning that the higher the condition of the company will result in the higher attitude of employees towards the application of HRIS.

The use of new technologies and systems requires company readiness from various aspects, such as costs, technology infrastructure information and communication, readiness of human resources, easy application design and guaranteeing the confidentiality of employee personal data, legal devices, because HRIS is closely related to the creation, distribution of data or information and intellectual property rights which must be protected by law.

A system will run well if every important component in the system is fulfilled and can be provided by the company, as well as HRIS, which is an important aspect in a company. If company conditions can support the implementation of HRIS, surely employees will have a positive attitude towards the application of HRIS as a tool that can lighten their work and as a tool that can be used to improve employee performance and quality.

In connection with the covid-19 pandemic situation, the condition of the company in question does not only refer to readiness in implementing HRIS. However, conditions are also related to the difficulty of carrying out the work process because of the limitations of efforts from the government in order to reduce the spread of covid-19 and minimize the number of casualties caused by the virus. This is in accordance with the basic concept of acceptance of the use of information systems developed by Venkatesh et.al. (2003), that what is meant by conditions in this scope refers to all objective factors that encourage ease of use of information systems. Thus, the covid-19 pandemic condition can also be categorized as a factor that facilitates the use of HRIS because companies and employees are only faced with these alternatives to be able to carry out work and to connect more easily. 
In addition, the condition of the company which is currently in a critical period due to the limitations of all operational activities can also be considered as a driving factor for the increasingly urgent application of HRIS. When viewed from an employee's point of view, the implementation of HRIS can be a solution that can improve the condition of the company itself. Thus, the condition of the company which illustrates the company's ability to facilitate the implementation of HRIS and also describes the company's critical condition due to the Covid-19 pandemic will be able to encourage more positive employee attitudes towards HRIS implementation at PT XYZ.

HRIS as a digital version of HRM can function as a communication medium that allows companies and employees to connect even though they are physically far away. This is because employees are required to carry out work using a remote working model in the midst of the Covid-19 pandemic. Therefore, the benefits of implementing HRIS are increasingly being felt by both companies and employees. This is the basis for the significant influence between the benefits of HRIS on the attitude of employees of PT XYZ on the application of HRIS.

The application of an information system in a company often gets rejection from its employees because of the perception that the system is difficult to use, so its application will only increase the workload and pressure felt by employees. However, the outbreak of the Covid-19 pandemic opened the minds of employees about the importance of implementing a system that is able to overcome difficulties caused by the remote working model. In the context of this research, PT XYZ seeks to implement HRIS to ensure that all HRM activities can be carried out even though the company cannot interact directly and intensely with employees as before the virus developed. PT XYZ employees feel that HRIS is an information system that is easy to use and very important to implement, so the findings of this study state that the perception of the ease of use of HRIS at PT XYZ can encourage employee attitudes towards the implementation of HRIS to be more positive.

The implementation of HRIS requires the readiness of the company, both in terms of infrastructure, human resources, financial aspects, and readiness in other matters. If the company has conditions that are able to facilitate the optimal implementation of HRIS, employees will have the perception that the company is truly prepared to implement HRIS, so that the benefits of the information system will also be maximized. Conversely, if employees have the perception that the company is still not in a state that is truly ready to implement HRIS, then the benefits of the system will also not be felt. On the other hand, if the company is not ready, the implementation of HRIS will only be an additional burden for all parties, including employees, and this will have an impact on the negative attitude of employees towards the implementation of HRIS. However, in the conditions of the Covid19 pandemic, the application of HRIS is felt to be one of the hopes that will enable companies to survive the economic crisis that has occurred due to the spread of the virus. Employees understand the critical condition of the company, which is then used as an important consideration in addition to the company's readiness. This is what underlies the findings of this study which states that the condition of the company has a significant influence on employee attitudes towards the implementation of HRIS in PT XYZ.

Anand (2010) explains that the HRIS provides a wide range of positive effects for the company, among others: HRIS makes a wide range of enterprise into, from local to global reach, improve enterprise efficiency, especially in new employee recruitment efforts and 
reduce the costs of the company. This research supports this opinion, but this study also proves that to create an effective HRIS, 4 variables are needed in this study, namely the clarity of HRIS objectives, the benefits of using HRIS, ease of use of HRIS and HRIS company conditions, so that HRIS benefits can be obtained by the company optimally.

\section{CONCLUSION}

This research was conducted with the aim to find out how the clarity of the objectives of HRIS, the benefits of using HRIS, ease of use of HRIS and HRIS company conditions on employees attitudes regarding digital HRM, whether employees will be ready and able to apply HRIS in their office environment. The discussion to achieve the purpose of writing this study was carried out by linking the relationship between research variables with the current business situation amid various limitations of operational activities due to the Covid-19 pandemic.

Based on the collection and processing has been conducted found that all the independent variables in this study is clarity of purpose HRIS, benefits of using HRIS, ease of use and condition of the company HRIS have a significant effect on the dependent variable is the attitude of employees regarding digital HRM.

The purpose of implementing HRIS is basically to helps organizations in managing their human resources and provides added value to the role of HR in organizations that influence the competitive advantage of the organization, HRIS also helps organizations to improve service quality, in addition to that HRIS also provides efficiency time and cost for various activities in the organization. The aim of implementing HRIS can now be developed more broadly, namely to ensure the implementation of all HRM activities in the midst of the Covid-19 pandemic, and to ensure that problems experienced by employees in the form of high work pressure can be overcome. The existence of clarity regarding the various objectives of implementing HRIS is able to encourage the positive attitude of PT XYZ employees towards HRIS implementation.

In addition to the significant variables in this study, there are various other aspects that must be provided by the company before implementing HRIS such as ICT infrastructure, internet network availability, human resource readiness, application design that facilitates work and ensures the confidentiality of employee personal data, legal instruments, paradigm changes, where in this case the role of management is needed to change the paradigm, way of thinking, how to behave and how to work and behave so that employees can properly accept the application of HRIS in the organization, and finally the support of all parties in the organization.

\section{REFERENCES}

Anand, Sudhir and Martin Ravallion. 2010. "Human Development in Poor Countries: On the Role of Private Incomes and Public Services". The Journal of Economic Perspectives. Vol. 7. No. 1 (Winter, 2010):133- 150. https://doi.org/10.1257/jep.7.1.133

Ariani, S. \& Dalle, J. 2019. Effectiveness of administrative staff working in the study program state polytechnic Banjarmasin in using integrated information system (SIMPADU). Journal of information technology \& software engineering, 9(1): 1-5. https://doi.org/10.35248/2165-7866.19.9.253 
Bondarouk Tanya, Ruel Huub. 2014. EHRM: Innovation or Irritation (An explorative empirical study in five large companies on web-based HRM). Human Resource Management Journal, Vol 18, Hal 257 - 27.

Deil, S. A. 2015. 8 Ciri Karyawan Berkualitas di Tempat Kerja. 2018. http://bisnis.liputan6.com/read/2193216/8-ciri-karyawan-berkualitas-ditempat-kerja. Accessed $2^{\text {nd }}$ December 2019.

Edy, Sutrisno.2016. Manajemen Sumber Daya Manusia, Kencana Prenada Media Group, Jakarta.

Ghozali, Imam. 2016. Aplikasi Analisis Multivariate Dengan Program IBM SPSS 23 (Edisi 8). Cetakan ke VIII. Semarang: Badan Penerbit Universitas Diponegoro.

Hasibuan, Malayu S.P. 2016. Manajemen Sumber Daya Manusia. Bumi Aksara, Jakarta.

Kaushik, M. \& Guleria, N. 2020. Employee relations and engagement during covid-19. Sparkling international journal of multidisciplinary research studies, 3(2); 1-11.

Mahedi Sayed, Fartash Kiarash, 2012. EHRM: News Avenues Which Leads To Organizational Success. A Journal of Multidisciplinary Research Vol.1, ISSN 22780637. Hal 75 - 87.

Mangkunegara, A. P. 2013. Manajemen Sumber Daya Manusia Perusahaan, Remaja Rosdakarya, Bandung.

Marler H. Janet, Fisher. L. 2014. An Evidence-Based Review of EHRM and Strategic Human Resource Management. CEUR-WS.org. Vol 5. PP 33-51.

Marwansyah. 2010. Manajemen sumber daya manusia. Alfabeta: Bandung.

Mauro, T.G. \& Borges-Andrade, J.E. 2019. Human resource system as innovation for organizations. Innovation \& management review, 17(2): 197-214. https://doi.org/10.1108/INMR-03-2019-0037.

Pant Somendra, Chatterjee Abha, Jaroliya Deepak. 2012. e-HRM Systems Implementation: A Conceptual Framework. Volume 4 Issue 1. Hal 23 - 35

Parry Emma. 2011. An examination of e-HRM as a means to increase the value of the HR function. The International Journal of Human Resource Management, Volume 22, Issue 5. Hal 1146- 1162. https://doi.org/10.1080/09585192.2011.556791

Pich, K. \& Sardjono, W. 2020. The performance of information systems in facilitating work communication by online-based application during covid-19 pandemic crisis. Airlangga journal of education management, 1(1): 21-31. https://doi.org/10.20473/ajim.v1i1.19398

Rahayuningsih, S., Matulessy, A., Rini, A., \& Pandin, M. G. R. (2019). The Local Government Transformation, the Big Five Personality, and Anxiety. Opcion, 35(88), 759-770.

https://produccioncientificaluz.org/index.php/opcion/article/view/24225/24675.

Shil, M., Barman, R.C., Zayed, N.M., Shahi, S.K., \& Nelov, A.H. 2020. Global transition of HR practices in covid-19 pandemic situation: a systematic review through 5P's model of HRM. Management and Human Resource Research Journal, 9(6): 50-57.

Sholihin, Mahfud, Ph.D dan Ratmono Dwi. 2013. "Analisis SEM-PLS dengan Warppls 3.0 untuk Hubungan Nonlinier dalam Penelitian Sosial dan Bisnis". Penerbit Andi Offset. Yogyakarta.

Sugiyono. 2017. Metode Penelitian Kuantitatif, Kualitatif, dan R\&D. Bandung: Alfabeta, CV. 
Supomo. 2013. Metodologi Penelitian Bisnis Untuk Akuntansi dan Manajemen, BPFE, Yogyakarta.

Syamsudin Noor. 2014. Pengaruh Pemberian-Pemberian Insentif dan Disiplin Kerja Terhadap Kinerja Karyawan Pada PT Ben Line Agencies (BLA) Banjarmasin. Jurnal Socioscientia, 6 (1), 1-44. Diperoleh tanggal 7 November 2014.

Tavakoli, S., Ahmadi, S. A. K., Heidary, P. P. 2014. Perceived Organizational Support and Employee Engagement. International Journal of Information Technology and Management Studies. Vol. 1 Issue 1: 55- 67. February 2014.

Venkatesh, V., Morris, M.G., Davis, G.B., \& Davis, F.D. 2003. User acceptance of information technology: toward a unified view. MIS Quarterly, 27(3): 425-478. https://doi.org/10.2307/30036540.

Yu, X., Zhao, Y., Hu. C., Xu, H., Zhao, X., \& Huang, J. 2020. Factors associated with job satisfaction of frontline medical staff fighting against covid-19: a cross-sectional study in China. Front. Public health, 8(426): 1-9. https://doi.org/10.3389/fpubh.2020.00426.

Yusliza Mohd, Ramayah. T., Ibrahim Haslindar. 2014. E-HRM: A proposed model based on technology acceptance model. African Journal of Business Management Vol. 4 (13), PP. 3039-3045. 